\title{
Article \\ Fragrance in Pandanus amaryllifolius Roxb. Despite the Presence of a Betaine Aldehyde Dehydrogenase 2
}

\author{
Vacha Bhatt ${ }^{1}$, Vitthal T. Barvkar ${ }^{1}\left(\mathbb{D}\right.$, Agnelo Furtado $^{2}$, Robert J. Henry ${ }^{2} \mathbb{D}$ and Altafhusain Nadaf ${ }^{1, * \mathbb{C}}$ \\ 1 Department of Botany, Savitribai Phule Pune University, Pune 411007, India; vacha.biotech@gmail.com (V.B.); \\ vbarvkar@gmail.com (V.T.B.) \\ 2 Queensland Alliance for Agriculture and Food Innovation (QAAFI), The University of Queensland, \\ St Lucia, QLD 4072, Australia; a.furtado@uq.edu.au (A.F.); robert.henry@uq.edu.au (R.J.H.) \\ * Correspondence: abnadaf@unipune.ac.in
}

check for

updates

Citation: Bhatt, V.; Barvkar, V.T.; Furtado, A.; Henry, R.J.; Nadaf, A. Fragrance in Pandanus amaryllifolius Roxb. Despite the Presence of a Betaine Aldehyde Dehydrogenase 2. Int. J. Mol. Sci. 2021, 22, 6968.

https: / / doi.org/

10.3390/ijms22136968

Academic Editor: Leszek

A. Kleczkowski

Received: 27 April 2021

Accepted: 24 June 2021

Published: 28 June 2021

Publisher's Note: MDPI stays neutral with regard to jurisdictional claims in published maps and institutional affiliations.

Copyright: (c) 2021 by the authors. Licensee MDPI, Basel, Switzerland. This article is an open access article distributed under the terms and conditions of the Creative Commons Attribution (CC BY) license (https:// creativecommons.org/licenses/by/ $4.0 /)$.

\begin{abstract}
Pandanus amaryllifolius Roxb. accumulates the highest concentration of the major basmati aroma volatile 2-acetyl-1-pyrroline (2AP) in the plant kingdom. The expression of 2AP is correlated with the presence of a nonfunctional betaine aldehyde dehydrogenase 2(BADH2) in aromatic rice and other plant species. In the present study, a full-length $B A D H 2$ sequence was reconstructed from the transcriptome data of leaf tissue from P. amaryllifolius seedlings. Based on this sequence, a $1509 \mathrm{bp}$ coding sequence was defined that encoded a $54 \mathrm{kD} \mathrm{PaBADH} 2$ protein. This revealed the presence of a full-length BADH2 protein in P. amaryllifolius. Moreover, quantitative real-time PCR analysis, combined with BADH2 enzyme activity, confirmed the expression and functionality of the PaBADH2 protein. To understand the apparent structural variation, docking analysis was carried out in which protein showed a good affinity with both betaine aldehyde (BAD) and $\gamma$-aminobutyraldehyde (GABald) as substrates. Overall, the analysis showed the presence of a functional BADH2, along with substantial 2AP synthesis (4.38 ppm). Therefore, we conclude that unlike all other plants studied to date, 2AP biosynthesis in P. amaryllifolius is not due to the inactivation of BADH2.
\end{abstract}

Keywords: P. amaryllifolius; betaine aldehyde dehydrogenase 2; 2-acetyl-1-pyrroline; $\gamma$-aminobutyraldehyde

\section{Introduction}

Among the 750 Pandanus species, Pandanus amaryllifolius is the only species that produces the major basmati aroma compound 2-acetyl-1-pyrroline (2AP) in leaves. The species accumulates $2 \mathrm{AP}$ at the highest concentrations reported in the plant kingdom [1-3]. Leaves of P. amaryllifolius areroutinely used to flavor different food dishes in Southeast Asia [4]. In India, it was introduced in 1798, through the Botanical garden of Kolkata [5] and popularly cultivated along the Indian peninsular in kitchen gardens as a spice.

This species has been extensively studied in the laboratory of AN as follows. Bag-like structures called epidermal papillae were identified on the lower epidermis of the leaves of this species and act as a site of storage for 2AP [6]. Their pattern of development has been studied in the in vitro raised seedlings that showed that stomata act as the epicenter for its development [7]. A total of 21 new volatiles in this species have been identified [8]. Further, in vitro regeneration protocol has also been standardized. The populations of $P$. amaryllifolius grown under a wide range of environmental conditions across the Indian peninsular regions were collected and an elite population with the highest 2AP contents (12.2 ppm) was identified [9].These populations displayed remarkable genetic similarity.

We now report an investigation of the molecular basis of the extreme 2AP accumulation in this species. In aromatic rice and other plant species, 2AP synthesis is correlated with the presence of a nonfunctional $B A D H 2$ gene [10]. A mutation in the $B A D H 2$ gene introducing a premature stop codon causes loss of gene function and starts accumulating GAB-ald, a substrate of BADH2, and this GAB-ald spontaneously reacts with methylglyoxal to produce 2AP [11]. Fitzgerald et al. [12] reported that $B A D H 2$ is playing a crucial 
role in maintaining the yield under salt stress and under exposure to stress conditions fragrant rice varieties with nonfunctional $B A D H 2$ is more susceptible to yield loss. A detailed understanding of the enzymatic and molecular mechanism of BADH2 in Pandanus can help to resolve the issue of stress susceptibility in fragrant rice. The BADH2 enzyme belongs to the aldehyde dehydrogenase (ALDH) super family. Members of this family possess substrate-binding, $\mathrm{NAD}^{+}$-binding, and oligomerization domains. The total loss of activity was observed associated with a mutation in Cys294 to alanine in the catalytic site of BADH2 [13-15]. Similarly, loss of activity was reported with a Glu260 to alanine mutation, and a reduced enzyme affinity was observed with an Asn162 to alanine mutation. Numerous studies have been carried out to identify the precursors of 2AP in various plant species. These studies reported that proline, ornithine, and glutamate act as the primary precursors of 2AP synthesis in P. amaryllifolius $[16,17]$ and rice $[18,19]$.

Although the economic importance of P. amaryllifolius is attributed to the aroma, limited information is available regarding the structure and specificity of BADH2 in this species. An earlier report [20] showed the presence of a truncated allelic form of the $B A D H 2$ gene in in vitro plantlets of P. amaryllifolius (PND BADH2, gene ID: KY765936.1). Furthermore, in silico analysis suggested that insufficient affinity between the PaBADH2 enzyme and its substrate GAB-ald might be the major determinant of aroma development in P. amaryllifolius. Here, we obtained the full-length functional $\mathrm{PaBADH} 2$ sequence from the transcriptome analysis and characterized its enzymatic activity, gene expression, protein sequence, active site, and interaction with a substrate.

\section{Results}

\subsection{De Novo Transcriptome Assembly and Analysis}

RNAseq data from the leaf of P. amaryllifolius was used to perform de novo assembly of the transcriptome. Raw data comprising 37,583,042 reads were obtained from the library. The SRA sequences were submitted to NCBI (BioProject ID: PRJNA692823). After removing the low-quality reads and all possible contamination, a total of 29,464,902 clean reads with $\mathrm{Q} \geq 30$ and $46 \%$ of GC content were obtained. Trinity-based de novo assembly generated contigs with N25 of $1663 \mathrm{bp}$, N50 of $1010 \mathrm{bp}$, and N75 of $555 \mathrm{bp}$. The N50 value of assembly is the sequence length of the shortest contig at $50 \%$ of the total transcriptome assembly length. It is a length-weighted median. N50 statistic defines assembly quality in terms of contiguity. Likewise, N25 and N75 are the minimum contig length to cover $25 \%$ and $75 \%$ of transcriptome assembly, respectively. A total of 34,672 transcript sequences were produced that had an average transcript size of $802 \mathrm{bp}$. A total of 27,734 transcripts had homologous genes in the NCBI nt database, while 6938 transcripts had no significant homology to any known genes. The assembly statistics are given in Supplementary Table S1.

\subsection{Isolation of PaBADH2 Transcriptome Sequence and Its Comparison with Other BADH2 Sequences}

A full-length transcript sequence of $\mathrm{PaBADH} 2$ was isolated from the assembled transcriptome using homology-based criteria and the transcript was found to be $1989 \mathrm{bp}$ long. The sequence comprises a $5^{\prime}$ UTR from nucleotide 1 to 116 and a $3^{\prime}$ UTR from nucleotide 1629 to 1988. The gene sequence was compared with the previously reported PND BADH2 and a nonscented rice $O s B A D H 2$ sequence. There were several mismatches observed between $P a B A D H 2$ and PND BADH2 gene sequences. To confirm the reconstructed sequence, the raw sequencing reads were mapped onto the assembled BADH2 from P. amaryllifolius and this revealed that a total of 1762 reads mapped to the PaBADH2 (1512 bp) sequence that supported the full-length sequence of an apparently functional transcript (Figure 1). 


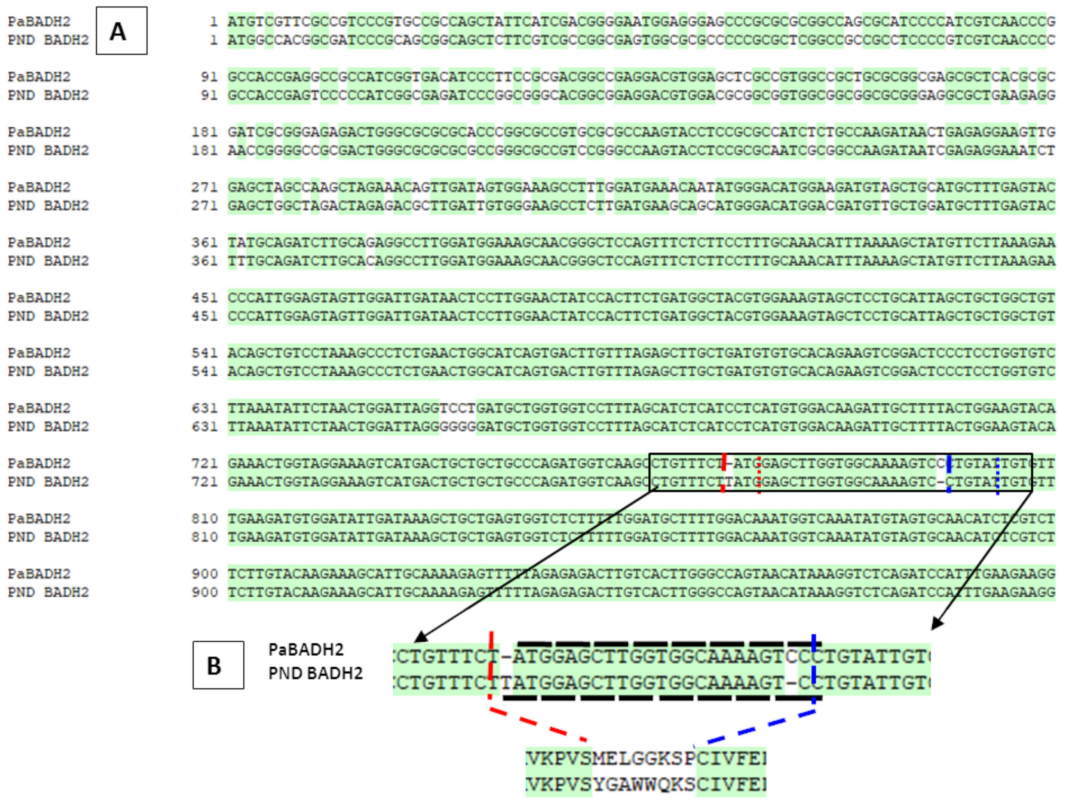

C

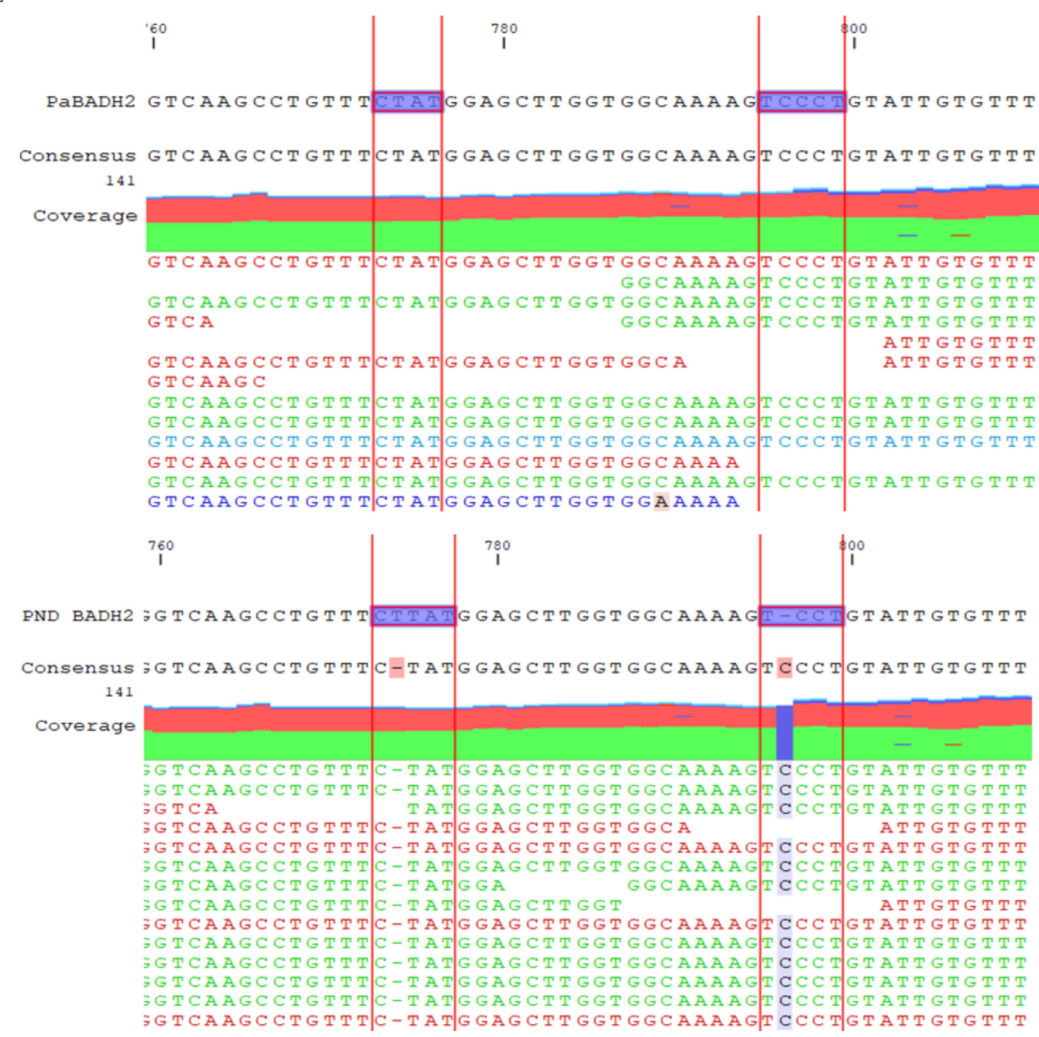

Figure 1. Mapping-based evidence for presence of the $\mathrm{PaBaDH} 2$ gene in P. amaryllifolius genotype. PaBADH2 and PND BADH2, Betaine aldehyde dehydrogenase gene of Pandanus amaryllifolius from the present study and Arora et al. (2017), respectively: (A,B) alignment of the PaBADH2 and the PND $B A D H 2$ genes showing several mismatches including the insertion of the T nucleotide and the deletion of the $\mathrm{C}$ nucleotide at each end of the $24 \mathrm{bp}$ region indicated with red and blue broken vertical lines and the consequential change in the amino acid sequence; $(\mathbf{C})$ mapping of whole-genome Illumina reads of $P$. amaryllifolius to the $P a B A D H 2$ and the $P N D B A D H 2$ as reference sequences indicates the reads, showing no evidence of the $\mathrm{T}$ nucleotide insertion and the deletion of the $\mathrm{C}$ nucleotide at each end of the 24 bp sequence. 


\subsection{Comparative Amino Acid Sequence Analysis}

The $P a B A D H 2$ transcript included an open reading frame with 1509 nucleotides encoding a 503 amino acid full-length sequence, which would translate to a $54 \mathrm{kD}$ functional protein. A peptide sequence (VSYGAWWQKS) and a cysteine residue (28th amino acid from the conserved peptide sequence), which was reported to be highly conserved in the proteins of aldehyde dehydrogenase, was observed in PaBADH2. Another characteristic conserved peptide, EGCRLGPVVS, reported in betaine dehydrogenases, was also present in PaBADH2. This finding suggests the presence of functional BADH2 protein in P. amaryllifolius. The $\mathrm{PaBADH} 2$ gene contains a C-terminal SKL sequence, suggesting that the protein is targeted to the peroxisomes.

The comparative sequence alignment of $\mathrm{PaBADH} 2$ and the previously reported sequence, PND BADH2 [20] exhibited $91.7 \%$ sequence similarity. The analysis also showed that most of the amino acid sequences were conserved between them except for a major consecutive 8 amino acid variation present at the middle of the PaBADH2 sequence. A critical amino acid of the catalytic domain of functional BADH2, Glu260, was present in PaBADH2, while it was mutated to glycine in PND BADH2. PaBADH2 showed 79.3\% sequence identity with the rice sequence, OsBADH2 (Figure 2). Although there were some variations in the amino acid sequence of PaBADH2 relative to the OsBADH2 sequence, the formation of full-length protein was not hampered. The predicted amino acid sequence for PaBADH2 suggested the presence of a full-length functional protein because the differences in the sequences were not in the conserved amino acids that are important for enzyme activity.

\subsection{Docking Analysis}

To uncover possible functional differences between OsBADH2 and PaBADH2, protein docking analysis was carried out using BAD and GAB-ald as substrates (Figures 3 and 4). The three-dimensional structure of the $\mathrm{PaBADH} 2$ protein was developed and enzymesubstrate interaction was studied using protein docking where BAD was used as the substrate for BADH2. With GAB-ald, the interaction energy for a monomer of PaBADH2 and OsBADH 2 was $-3.3 \mathrm{kcal} / \mathrm{mole}$ and $-3.2 \mathrm{kcal} / \mathrm{mole}$, respectively, whereas, in the case of $\mathrm{BAD}$, it was $-5.1 \mathrm{kcal} / \mathrm{mole}$ and $-5.2 \mathrm{kcal} / \mathrm{mole}$, respectively. The conserved amino acids of the NAD+ catalytic domains are almost identical in both proteins. The active site of PaBADH2 for substrate binding comprised of, Ile158, Thr159, Pro160, Lys185, Ser187, Glu188, Phe236, Gly238, Ser239, and Thr242. Likewise, the active site of OsBADH2 consists of Glu297, Leu300, Phe301, Phe304, Trp305, Trp334, Ile338, and Arg349. From this analysis, interactions were found in the complexes between hydrogen bonds, ionic bonds, $\mathrm{C}-\mathrm{H}$ bonds, and Van der Waals interactions. The BAD interacted with the active site of PaBADH2 via two hydrogen bonds $\left(2.1 \mathrm{~A}^{0}\right)$, two $\mathrm{C}-\mathrm{H}$ bonds $\left(3.49 \mathrm{~A}^{0}\right)$, one ionic interaction $\left(4.64 \mathrm{~A}^{0}\right)$, and six Van der Waals interactions $\left(3.16 \mathrm{~A}^{0}\right)$. In this reaction, the hydroxyl group containing amino acids Ser 239 and Thr242 from the active site of the enzyme were associated in hydrogen bond formation with a ligand molecule. Moreover, the nucleophilic nature of the tertiary amine of the substrate allows the formation of an ionic bond with Glu188 present in the active site of the enzyme. Thr159 and Thr237 were present close to the substrate forming a strong C-H bond. Other than these, Phe236, Gly238, Lys185, Ser187, and Ile158 were involved in the Van der Waals interaction. In the same way, OsBADH2 also contained Glu297 that formed ionic interaction with the ligand, whereas other amino acids such as Leu300, Phe301, Phe304, Trp305, Trp334, Ile338, Arg349 were engaged in Van der Waals bond formation with the substrate. Overall, the docking analysis of both $\mathrm{PaBADH} 2$ and $\mathrm{OsBADH} 2$ suggested that there was not much difference in the interaction energies and the bond formation in the active site of both the enzymes; hence, it can be said that the PaBADH2 enzyme is likely to have similar activities. 
CLUSTAL O(1.2.4) multiple sequence alignment

\begin{tabular}{|c|c|c|}
\hline $\mathrm{OSBADH} 2$ & - -TAIPQRQLFVAGEWRAPALGRRLPVWNPATESPIGEIPAGTAEDVDAAVAAAREALKR & 58 \\
\hline PaBADH2 & MSFAVPCRQLFIDGEWREPARGQRIPIVWPATEAAIGDIPSATAEDVELAVAAARRALTR & 60 \\
\hline PNDBADH2 & 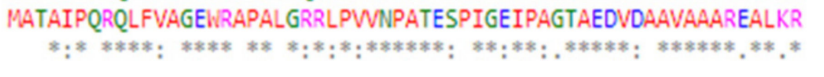 & 60 \\
\hline $\mathrm{OSBADH} 2$ & NRGRDUARAPGAVRAKYLRAIAAKIIERKSELARLETLDCGKPLDEAAWDMDDVAGCFEY & 118 \\
\hline PaBADH2 & DRGRDWARAPGAVRAKYLRAISAKITERKLELAKLETVDSGKPLDETINDMEDVAACFEY & 120 \\
\hline PNDBADH2 & $\begin{array}{l}\text { NRGRDWARAPGAVRAKYLRAIAAKIIERKSELARLETLDCGKPLDEAAINDIIDDVAGCFEY } \\
: * * * * * * * * * * * * * * * * * *: * * * * * * * *: * * *: * * * * * *: * * *: * * * * * * *\end{array}$ & 120 \\
\hline $\mathrm{OSBADH} 2$ & FADLAESLDKRQNAPVSLPMENFKCYLRKEPIGVGLITPWINYPLLMATWKVAPALAAGC & 178 \\
\hline PaBADH2 & YADLAEALDGKQRAPVSLPLQTFKSWLKEPIGVGLITPWINYPLLMATWKVAPALAAGC & 180 \\
\hline PNDBADH 2 & $\begin{array}{l}\text { FADLAQALDGKQRAPVSLPLQTFKSWLKEPIGVGLITPVINYPLLMATWKVAPALAAGC } \\
: * * * *::^{* * *}: * * * * *:: * * ;: * * * * * * * * * * * * * * * * * * * * * * * * * *\end{array}$ & 180 \\
\hline $\mathrm{OSBADH} 2$ & TAVLKPSELASVTCLELADVCKEVGLPSGVLNIVTGLGSEAGAPLSSHPGVDKVAFTGSY & 238 \\
\hline $\mathrm{PaBADH} 2$ & TAVLKPSELASVTCLELADVCTEVGLPPGVLNILTGLGPDAGGPLASHPHVDKIAFTGST & 240 \\
\hline PNDBADH2 & $\begin{array}{l}\text { TAVLKPSELASVTCLELADVCTEVGLPPGVLNILTGLGGDAGGPLASHPHVDKIAFTGST } \\
* * * * * * * * * * * * * * * * * * *, * * * * * * * * *: * * * *::^{* *}, * *: * * * * * *: * * * * *\end{array}$ & 240 \\
\hline $\mathrm{OSBADH} 2$ & ETGKKIMASAAPFIVKVVSLELGGKSPI VFDDVDVEKAVEWTLFGCFWTNGQICSATSRL & 298 \\
\hline PaBADH2 & ETGRKVMTAAAQYVKPVSI:ELGGKSPCVFEDVIDKAAEWSLFGCFWTNGQICSATSRL & 300 \\
\hline PNDBADH2 & 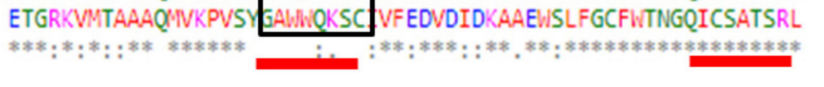 & 300 \\
\hline $\mathrm{OSBADH} 2$ & ILHKKIAKEFQERMVANAKNIKVSDPLEEGCRLGPWSEGQYEKIKQFVSTAKSQGATIL & 358 \\
\hline PaBADH2 & LVQESIAKEFLERLVTWASNIKVSDPFEEGCRLGPWSQGQYAKIKKFISTAKSEGATIL & 360 \\
\hline PNDBADH2 & 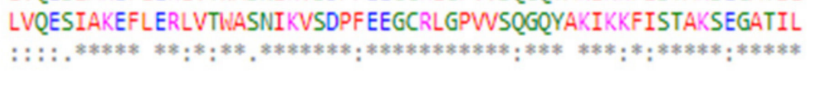 & 360 \\
\hline $\mathrm{OSBADH} 2$ & TGGVRPKHLEKGFYIEPTIITDVDTSMQIWREEVFGPVLCVKEFSTEEEAIELANDTHYG & 418 \\
\hline PaBADH2 & FGGGRPKHLEKGFFIEPTIIIDVNTSMQIWREEVFGPVLCVKIFKTEDEAIELANDSHYG & 420 \\
\hline PNDBADH2 & $\begin{array}{l}\text { FGGGRPKHLEKGFFIEPTIIIDVNTSMQIWREEVFGPVLCVKIFKTEDEAIELANDSHYG } \\
\qquad * * * * * * * * * * *: * * * * * * * *: * * * * * * * * * * * * * * * * * * *, * *: * * * * * * * *: * * *\end{array}$ & 420 \\
\hline $\mathrm{OSBADH} 2$ & LAGAVLSGDRERCQRLTEEIDAGIIWVNCSQPCFCQAPWGGNKRSGFGRELGEGGIDNYL & 478 \\
\hline PaBADH2 & LAGAVLSKDSERCKRMMEAIQAGVIWVNCSQPCFCQAPWGGTKRSSFGRELGEWGLENYL & 480 \\
\hline PNDBADH2 & 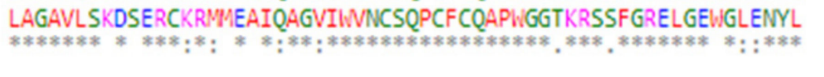 & 480 \\
\hline $\mathrm{OSBADH} 2$ & SVKQVTEYASDEPWGWYKSPSKL & \\
\hline PaBADH2 & SVKQVTEYISDEPWGWYPSPSKL 503 & \\
\hline PNDBADH 2 & $\begin{array}{l}\text { Conserved region of } \\
\text { aldehyde } \\
\text { dehydrogenase doma }\end{array}$ & \\
\hline
\end{tabular}

Figure 2. Multiple sequence alignment of BADH2 protein sequence from OsBADH2 (gene ID: 4345606), PND BADH2 (gene ID: KY765936.1), and PaBADH2. The marked region shows the continuous stretch of eight amino acid variations in PND BADH2, as compared with OsBADH2 and PaBADH2 sequences. The conserved region of the aldehyde dehydrogenase domain is represented with red lines. 


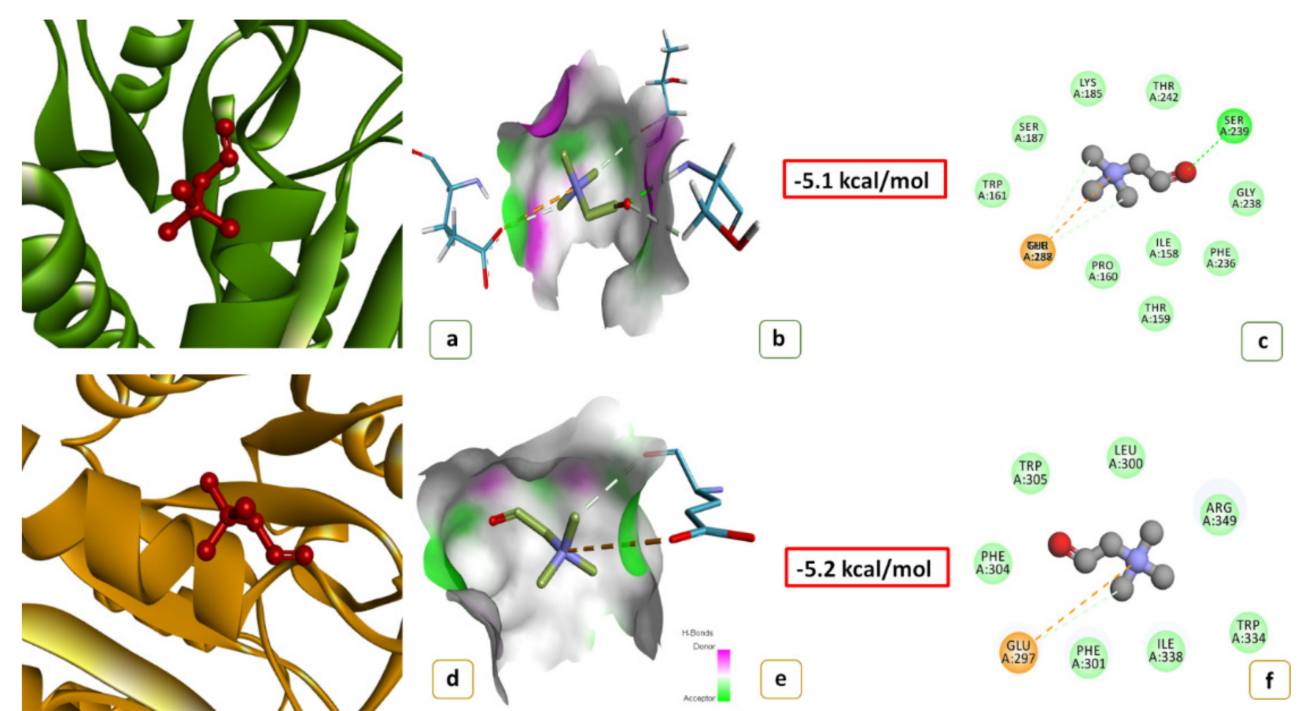

Figure 3. Docking analysis of PaBADH2 with betaine aldehyde (BAD): (a) docked 3D structure of PaBADH2-BAD complex; (b) showing H-bond donor (pink) and acceptor (green) surfaces in PaBADH2-BAD complex; (c) the 2D view of interacting residues of PaBADH2-BAD complex at ligand binding site that involves H-bond (green circle), Van der Waals bond (light green circle) and electrostatic interaction (brown circle); (d) docked 3D structure of OsBADH2-BAD complex; (e) showing H-bond donor (pink) and acceptor (green) surfaces in OsBADH2-BAD complex; (f) the 2D view of interacting residues of OsBADH2-BAD complex at ligand binding site that involves H-bonds (green circle), Van der Waals bonds (light green circle), and electrostatic interaction (brown circle).
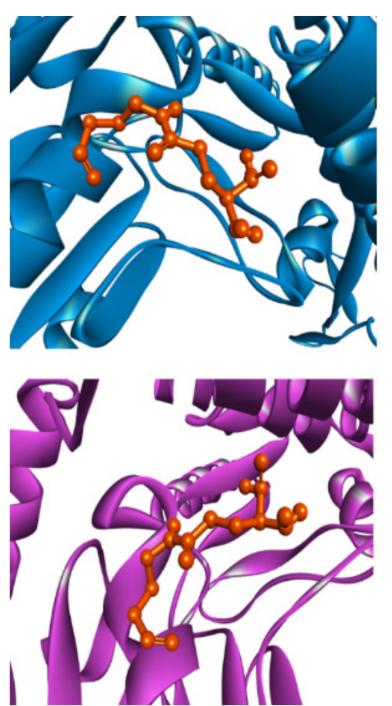
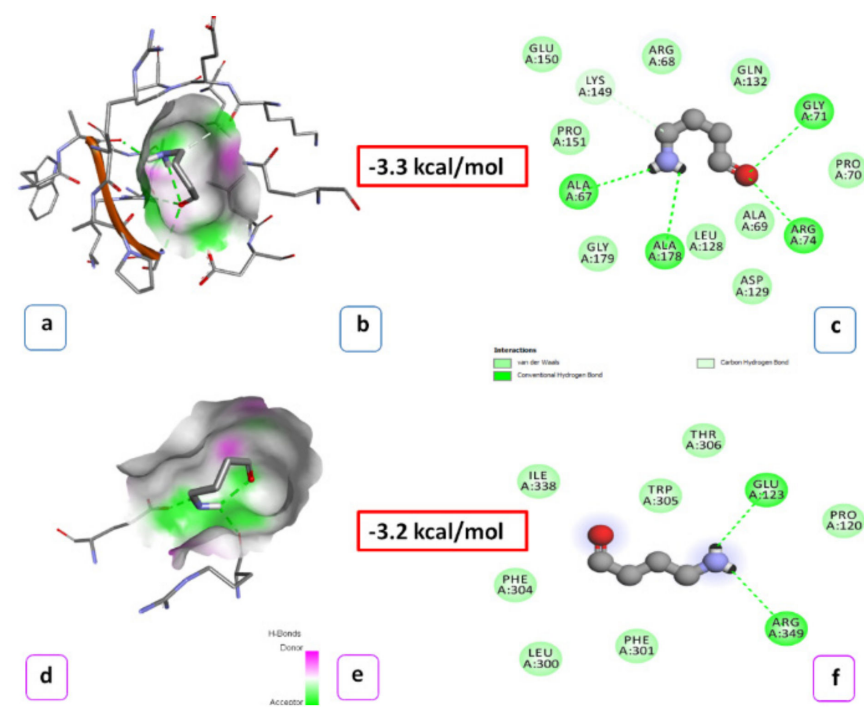
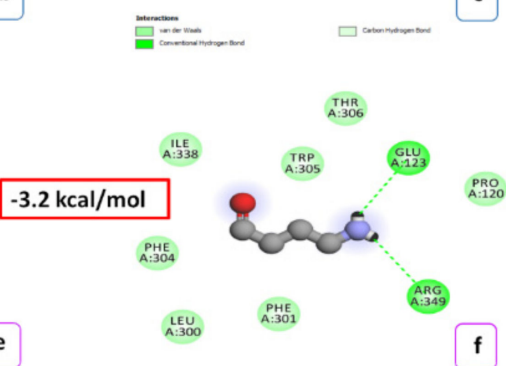

Figure 4. Docking analysis of PaBADH2 with 4-amino butaraldehyde (GAB-ald): (a) docked 3D structure of PaBADH2-GAB-ald complex; (b) showing H-bond donor (pink) and acceptor (green) surfaces in PaBADH2-GAB-ald complex; (c) the 2D view of interacting residues of PaBADH2- GABald complex at ligand binding site that involves H-bond (green circle) and Van der Waals bond (light green circle); (d) docked 3D structure of OsBADH2 GAB-ald complex; (e) showing H-bond donor (pink) and acceptor (green) surfaces in OsBADH2GAB-ald complex; (f) the 2D view of interacting residues of OsBADH2-GAB-ald complex at ligand binding site that involves H-bonds (green circle) and Van der Waals bonds (light green circle). 


\subsection{BADH2 Enzyme Activity and Gene Expression Analysis}

The BADH2 enzyme activity of P. amaryllifolius, Basmati 370 (scented rice), and IR 64 (nonscented rice) with GAB-ald as a substrate at $\mathrm{pH} 8.0$ was $40.0 \mathrm{nM} / \mathrm{min} / \mathrm{g}$, $23.9 \mathrm{nM} / \mathrm{min} / \mathrm{g}$, and $35.1 \mathrm{nM} / \mathrm{min} / \mathrm{g}$, respectively (Figure 5). With BAD as a substrate, the same assay depicted a different trend. P. amaryllifolius showed $73.6 \mathrm{nM} / \mathrm{min} / \mathrm{g}$, Basmati 370 showed $11.4 \mathrm{nM} / \mathrm{min} / \mathrm{g}$, and IR 64 showed $22.5 \mathrm{nM} / \mathrm{min} / \mathrm{g}$ enzyme activity. This confirms the presence of a functional BADH2 enzyme in P. amaryllifolius. Additionally, the study proves that $P$. amaryllifolius utilizes BAD substrate more efficiently than GAB-ald at $\mathrm{pH} 8$ and vice versa for the rice varieties. The expression analysis of the $\mathrm{PaBADH} 2$ gene (1.33 \pm 0.89 fold), OsBADH2 in Basmati 370 (1.00 \pm 0.081$)$, and IR 64 (1.65 \pm 0.98$)$ showed that it was upregulated in leaf tissue (Figure 4). This result further highlights the presence of the functional PaBADH2 gene in P. amaryllifolius.
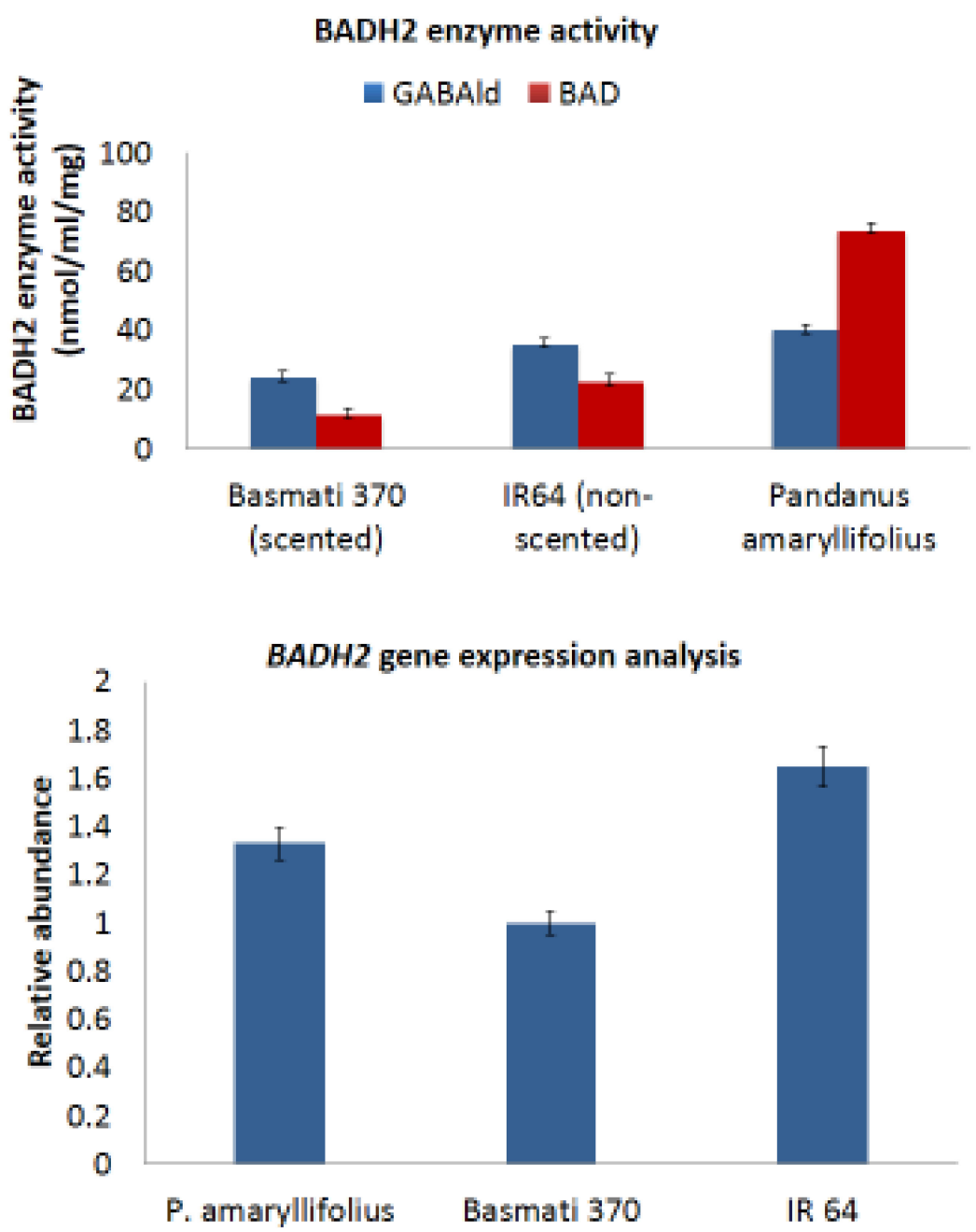

Figure 5. A comparative BADH2 enzyme activity using BAD and GAB-ald substrates and gene expression analysis in P. amaryllifolius and rice varieties. The EF1 gene was taken as a reference gene for normalization and relative abundance (fold change) was calculated by the $2^{-\Delta \Delta C t}$ method.

\subsection{Quantification of 2AP and Other Metabolites}

The highest amount of $2 \mathrm{AP}$ was recorded in P. amaryllifolius (4.38 ppm), followed by Basmati $370(0.20 \mathrm{ppm})$ and the absence of 2AP in IR 64 (Figure 6). The amount of 2AP in $P$. amaryllifolius was 20-22 times higher than that in the basmati rice varieties. Thus, $P$. amaryllifolius produces significantly higher concentrations of 2AP than fragrant rice. These results are in agreement with earlier reports [8]. Among the metabolites studied, free proline $(8.01 \mu$ moles $/ \mathrm{g})$ and methylglyoxal $(130 \pm 0.020 \mu \mathrm{M} / \mathrm{g})$ contents were highest in 
P. amaryllifolius. Yadav et al. [21] reported 62.3 and $74.8 \mu \mathrm{M} / \mathrm{g}$ of methylglyoxal in rice varieties IR 64 and PB1. This indicates that P. amaryllifolius contains an appreciably higher amount of methylglyoxal, as compared to nonscented rice varieties. Moreover, the same trend was followed by GABA content $(10.1 \mu \mathrm{g} / \mathrm{g})$. The concentration of GABA in various plant parts commonly ranges from 0.03 to $5.5 \mu \mathrm{g} / \mathrm{g}$ [22]. Rashmi and Nadaf [23] reported $15.0 \mu$ moles/g GABA in P. odorifer plants. The amount of GABA present in P. amaryllifolius was also considerably higher than in other plants.
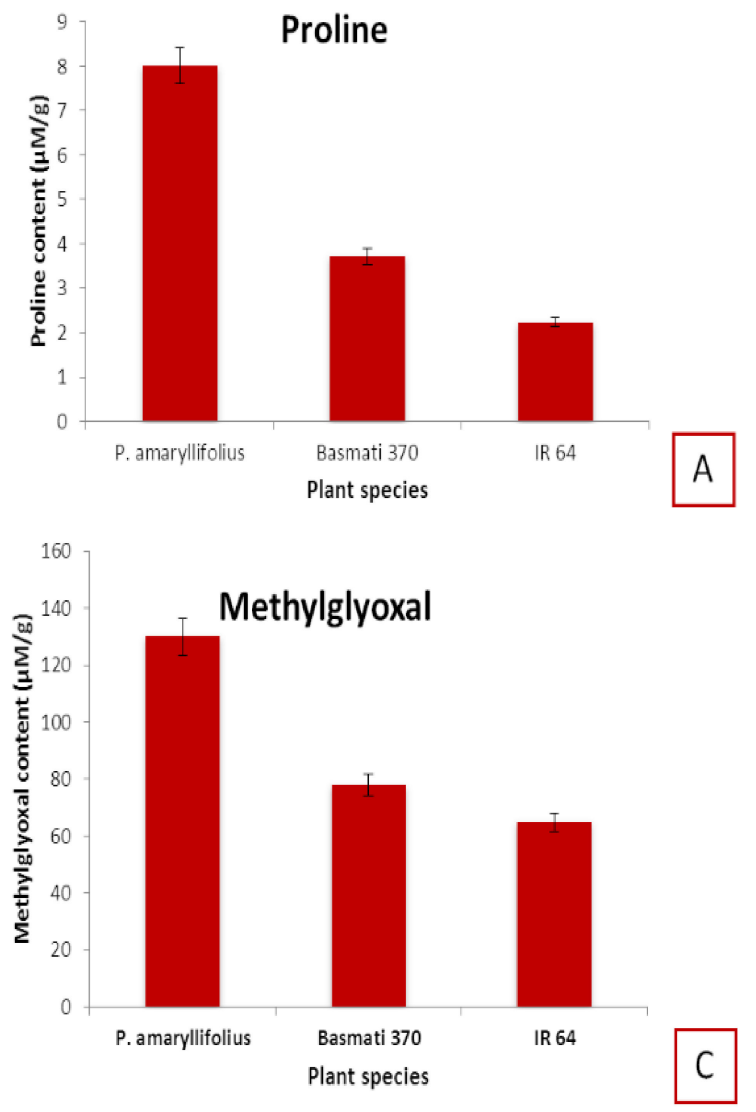
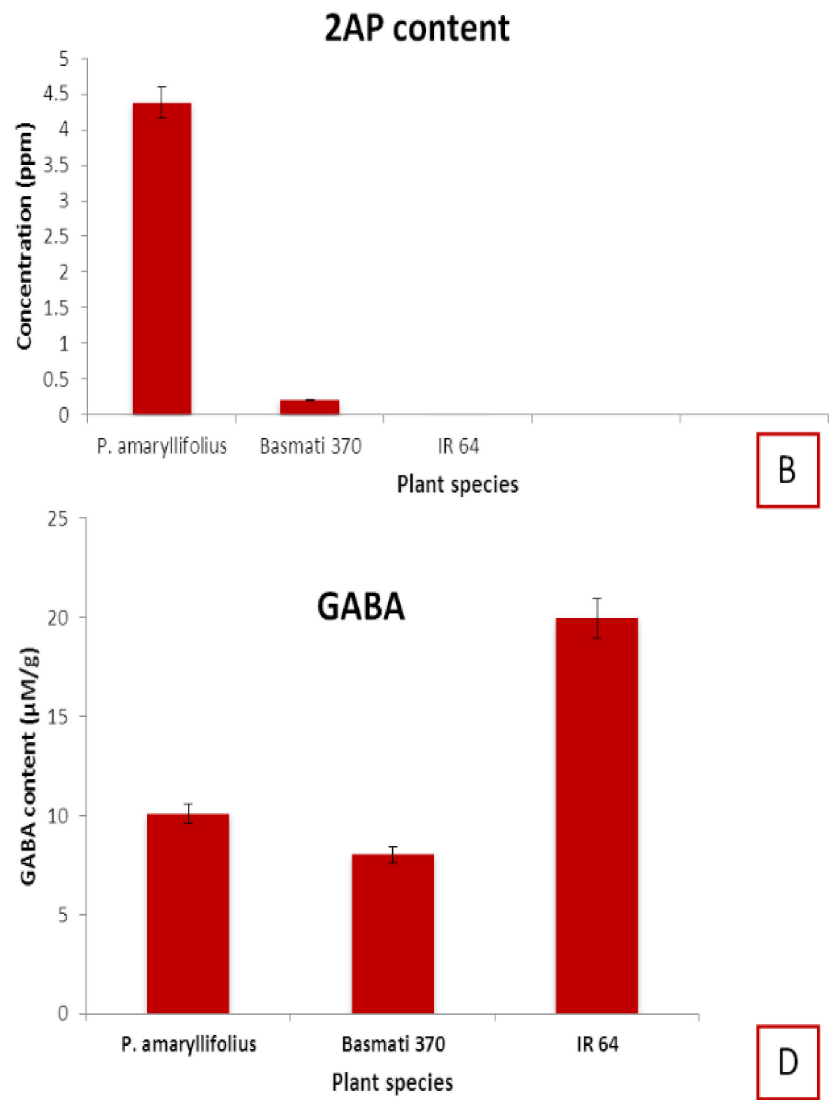

Figure 6. Comparative metabolite analysis in P. amaryllifolius, Basmati 370, and IR 64. The graph shows a comparative analysis of four key metabolites, namely, (A) proline, (B) 2AP, (C) methylglyoxal, and (D) GABA of 2AP biosynthetic pathway. Analysis was carried out in triplicates, and the standard deviation is represented with error bars. (Mean $\pm \mathrm{SE}, n=3$ ).

\subsection{Enzyme Activity of $\Delta 1$-Pyrroline-5-Carboxylate Synthetase (P5CS) and Expression Analysis}

The P5CS enzyme activity and transcript levels were found to be higher in P. amaryllifolius $(67.8 \pm 2.8 \mathrm{nM} / \mathrm{min} / \mathrm{g}$ and $2.00 \pm 0.71$ fold, respectively), which further correlates with the higher amount of proline and 2AP (Figure 7). P5CS enzyme is related to the enhancement of $\Delta 1$-pyrroline-5-carboxylic acid (P5C), thus resulting in the accumulation of higher 2AP. Kaikavoosi et al. [24] reported that overexpression of the P5CS gene enhanced the accumulation of proline, $\mathrm{P} 5 \mathrm{C}$, and $2 \mathrm{AP}$ in aromatic rice. 

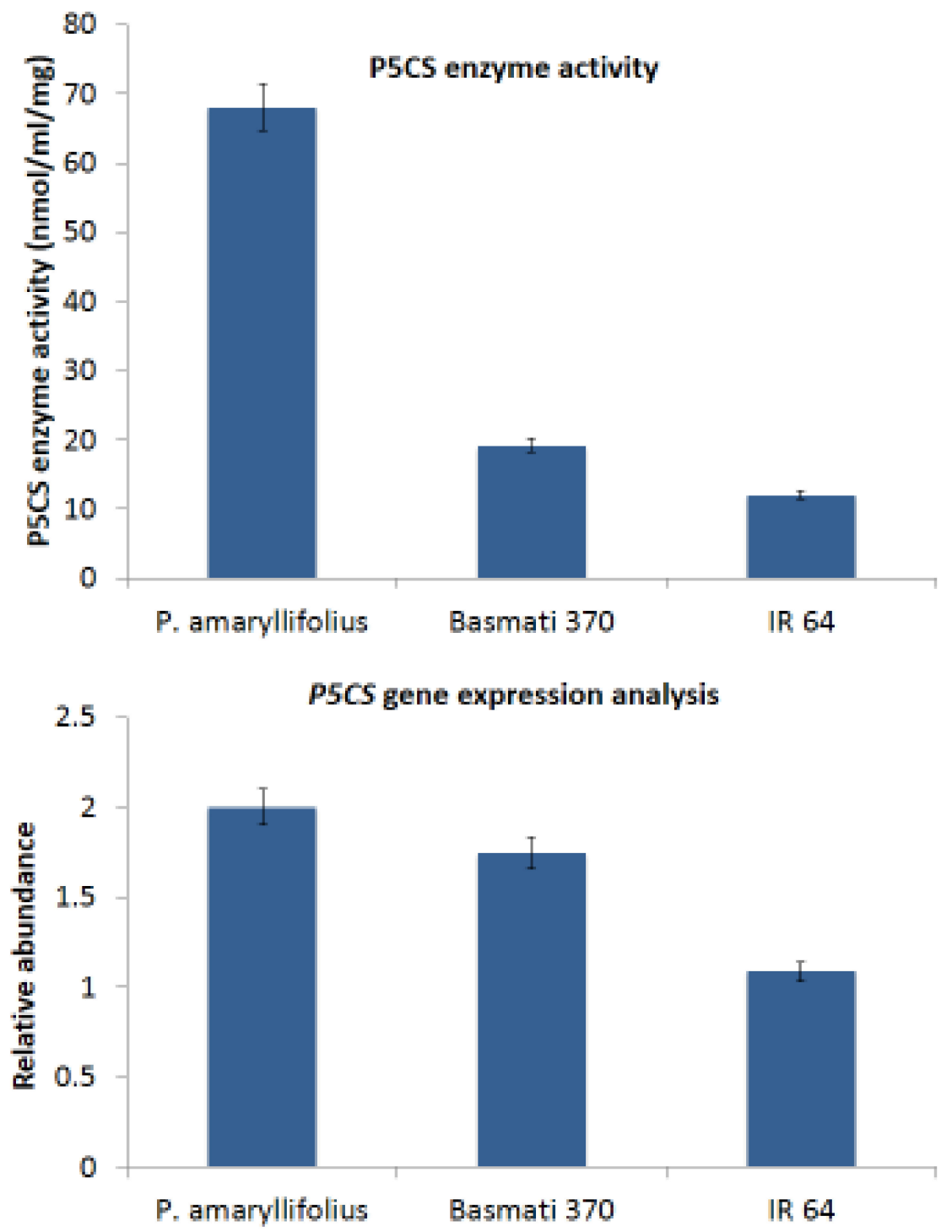

Figure 7. A comparative P5CS enzyme activity and gene expression analysis in P. amaryllifolius and rice varieties was carried out. The EF1 gene was taken as a reference gene for normalization and relative abundance was calculated by the $2^{-\Delta \Delta C t}$ method.

\section{Discussion}

\subsection{De Novo Transcriptomics Analysis}

De novo assembly and assessment of IIIuminaRNAseq data from P. amaryllifolius yielded a total of 27 million reads. Rashmi et al. [25] reported 28 million reads in P. odorifer, a species from the same genus. Both species have almost the same depth of sequencing. RNA seq data of P. odorifer showed an average transcript size of $951 \mathrm{bp}$ and N50 of $1821 \mathrm{bp}$, whereas in P. amaryllifolius, the average transcript size was $802 \mathrm{bp}$ and N50 of $1010 \mathrm{bp}$. This indicates that the average transcript size of $P$. odorifer is slightly longer than that of $P$. amaryllifolius, while the N50 value of the contigs showed variation in size.

\subsection{P. amaryllifolius Exhibits Functional BADH2 Gene}

One of the aims of the present study was the isolation and sequence characterization of $P a B A D H 2$ in P. amaryllifolius. The transcriptome analysis clearly revealed the expression of $P a B A D H 2$ with a single open reading frame without any stop codons. Further, the sequence alignment with functional OsBADH2 revealed over $79.3 \%$ sequence similarity. The homology between the conserved BADH2 domains indicated that this was a functional sequence. Arora et al. [20] reported BADH2 transcripts from in vitro P. amaryllifolius 
plantlets. When both the sequences were aligned, the length of the $P a B A D H 2$ sequence differed from the PND BADH2 gene sequence. This may be due to the presence of $5^{\prime}$ UTR and $3^{\prime}$ UTR. The sequence derived by transcriptome analysis showed the presence of $5^{\prime}$ UTR from nucleotides 1 to 116 and $3^{\prime}$ UTR from nucleotides 1629 to 1988. Further, the alignment of the $P a B A D H 2$ and the PND BADH2 genes showed several mismatches with a prominent variation of 24 base pairs, as depicted in Figure 1 . The several mismatches showed the insertion of a T nucleotide and the deletion of a $C$ nucleotide at each end of the $24 \mathrm{bp}$ region. The mapping of transcriptome reads to PaBADH2 and the PND BADH2 as reference sequences indicated that the reads show no evidence of the $T$ nucleotide insertion and the deletion of the $\mathrm{C}$ nucleotide at each end of the $24 \mathrm{bp}$ sequence. This analysis indicated the distinctness of this sequence from PND BADH2.

\subsection{Comparative Amino Acid Sequence Analysis}

Our data report the presence of a functional BADH2 protein in P. amaryllifolius. The comparative amino acid sequence alignment between PaBADH2 and OsBADH2 showed that there is no variation in conserved amino acids. Similar to OsBADH2, all three key amino acids are present in PaBADH2. These are not directly involved in the proteinligand interaction but provide a suitable framework that mediates the catalytic activity. As reported by Arora et al. [20], PND BADH2 does not produce a functional protein. The sequence alignment showed that in the PND BADH2 amino acid sequence, a crucial amino acid Glu260 is replaced by Glycine [20]. The conversion of acidic amino acid into a hydrophobic amino acid may be the reason that made PND BADH2 unable to form a suitable cavity for ligand and therefore explain why PND BADH2 might be nonfunctional. In contrast, the key amino acids involved in the reaction are conserved in PaBADH2 making it functional. Therefore, it can be inferred that the presence of conserved amino acids helped in the formation of the required cavity for the substrate, and the binding residues of the enzyme located at the exposed region provided a favorable interaction with the substrate. Hence, the PaBADH2 protein present in P. amaryllifolius showed functionality as it exhibits affinity and binding capacity with the substrate.

\subsection{Docking Analysis}

The variations in amino acid sequence were further studied by structural characterization of PaBADH2 protein through docking analysis. A comparative PaBADH2 and OsBADH2 homology modeling showed that the alignment of both models resulted in a 0.115 RMSD value. That claims that the 3D structures of both the proteins are closely similar without any major differences. That shows changes in amino acid sequence do not alter the 3D structure of the protein. To verify that it does not hamper the interaction between protein and substrate, docking analyses were carried out. In BADH2 enzymes, the NAD+ binding domain is mainly responsible for the conversion of intermediate aldehydes to their respective carboxylic acids. The crystal structure of AMADH from Spinacia oleracea, Pisum sativum [26], and Oryza sativa [27] have been studied. The 3D structure and simulation studies of OsBADH2 enzyme carried out by Baicharoen, Vijayan, and Pongprayoon [27] inferred that Asn162, Glu260, and Cys294 are prominent amino acids of the catalytic domains. The previous study in rice suggested this catalytic triad as crucial for the catalytic activity of ALDH. These three amino acids are conserved in many plant species. In the hemithioacetal enzyme formation, Cys294 and Glu260 are involved and Asn162 helps in the stabilization of an intermediate. In the protein-ligand interaction, the oligomerization domain shows little mobility, while during the interaction, the NAD+ domain shows maximum mobility. Asn162 and Glu260 form strong hydrogen bonds with nearby residues, resulting in a rigid conformation. The strong interaction network may help to shape a suitable cavity size and dimension that fits both substrate and cofactor. In contrast, Cys294 remained mobile inside the pocket. Numerous reports are available that show that mutation in any of the amino acids from this catalytic domain results in reduced enzyme-substrate affinity. The conversion of Asn162 to alanine resulted in a momentous 
reduction in enzyme affinity with the substrate, while a change of Glu260 to alanine led to a complete loss of enzyme activity [15,28,29]. Mutation in Cys294 to alanine was reported to entirely abolish the activity of the enzyme [13,14]. Kamaraj and Purohit [30] executed a comparative rice BADH2 enzyme interaction study using rice mutant lines BADH2 ${ }^{\mathrm{N} 162 \mathrm{~A}}$, $\mathrm{BADH} 2^{\mathrm{E} 260 \mathrm{~A}}$, and $\mathrm{BADH} 2^{\mathrm{C} 294 \mathrm{~A}}$. The docking analysis revealed that the protein structure developed by mutant lines showed a narrower binding pocket than the wild-type BADH2 protein, and it also exhibited lower interaction energy when docked with GAB-ald. The minimum enzyme interaction was found in $\mathrm{BADH} 2^{\mathrm{N} 162 \mathrm{~A}}$, followed by BADH2 ${ }^{\mathrm{E} 260 \mathrm{~A}}$ and $\mathrm{BADH} 2{ }^{\mathrm{C} 294 \mathrm{~A}}$. Therefore, it was concluded that these conserved amino acids play a major role in the establishment of appropriate binding cavity for better accommodation of the substrate. Any further changes in these conserved amino acids lead to change in the dynamics of the binding cavity, which, in turn, affects the enzyme-substrate interaction. Arora, Sultana, Kumar and Gangopadhyay [20] reported docking analysis in which they showed E260 as a conserved amino acid of substrate binding pocket; however, it is missing in their PND BADH2 sequence. The same amino acid is present in OsBADH2 and PaBADH2 sequences. Further, in the sequence, they reported glycine in place of glutamate (E260). This questions the authenticity of their sequence. In contrast, the docking analysis of our sequence confirms the functionality of PaBADH2.

The high PaBADH2 enzyme activity in vivo $(46 \mathrm{nM} / \mathrm{min} / \mathrm{g})$ confirmed these findings. Srivong et al. [31] reported BADH2 enzyme activity in aromatic (Khao Dawk Mali 105) and nonaromatic rice (Sew-Mae- Pah-Tawng) at $26 \mathrm{nmol} / \mathrm{min}$ and $37 \mathrm{nmol} / \mathrm{min}$, respectively. These results revealed higher BADH2 activity in P. amaryllifolius than in rice. GAB-ald and BAD are specific substrates of BADH2. Arakawa et al. [32] have also reported BADH2 activity in barley, wheat, and spinach as $0.17,0.22$, and $0.82 \mathrm{nM} / \mathrm{min} / \mathrm{mg}$ of total protein, respectively. These data support the existence of a functional BADH2 in P. amaryllifolius. Further, the qPCR analysis also revealed the existence of the $B A D H 2$ gene at the transcript level, which supports the functionality of the BADH2 protein.

\subsection{Role of Precursors in the High Expression of $2 A P$ in P. amaryllifolius}

P. amaryllifolius is a potent producer of 2AP. The $P$. amaryllifolius leaf tissue showed the presence of 2AP. Basmati rice has been reported to accumulate up to 1 ppm of 2AP and in the highly scented rice variety Khao Dawk Mali-105 up to 3 ppm of 2AP [33]. Yoshihashi, Nguyen, and Kabaki [19] reported relatively higher 2AP in the aerial parts of the rice plants when compared to the milled grains. Moreover, 2AP has been reported to be synthesized throughout rice plants except in the roots [34]. Similar to the reports for aromatic rice, the reports for 2AP indicate that it is synthesized in aerial parts of $P$. amaryllifolius. The presence of 2AP prompted us to analyze the precursors related to the 2AP biosynthetic pathway. Proline has been identified as a precursor amino acid for the biosynthesis of 2AP and higher concentrations have been reported to contribute to enhanced 2AP levels. Several reports have demonstrated the role of proline in 2AP pathway. Using tracer experiments with ${ }^{15} \mathrm{~N}$-proline, Huang et al. [34] demonstrated that the nitrogen of 2AP was derived from proline. Thimmaraju et al. [17] reported enhanced production of 2AP by feeding L-proline to the semi-differentiated callus culture of P. amaryllifolius. The maximum level of $22 \mathrm{mg} / \mathrm{kg}$ of $2 \mathrm{AP}$ was synthesized when rice calli were treated with $1 \mathrm{mmol} / 1$ of L-proline. Suprasanna et al. [18] demonstrated that proline addition enhanced the aroma in callus cultures of aromatic rice, suggesting that proline was related to aroma synthesis. Kaikavoosi et al. [24] overexpressed the P5CS gene in scented rice in order to achieve enhanced accumulation of proline, P5C, and 2AP. The leaf samples accumulated $8.07 \pm 0.09 \mu$ moles $/ g$ of free proline and a higher amount of P5CS enzyme activity $67.8 \pm 2.83$ with the presence of transcripts supporting the higher accumulation of 2AP in P. amaryllifolius leaves.

In addition to proline, methylglyoxal has also been identified as another precursor for the biosynthesis of 2AP. Wu et al. [35] reported higher $(1.9 \mu \mathrm{mol} / \mathrm{g}) \mathrm{MG}$ levels in aromatic than nonaromatic cultivars $(1.2 \mu \mathrm{mol} / \mathrm{g})$ of soybean. MG was identified as the 
carbon source for 2AP. Vegetable soybeans with higher levels of 2AP were reported to contain higher amounts of MG demonstrating a direct relation between MG and 2AP. They also demonstrated that an intermediate compound derived from proline reacts nonenzymatically with MG to produce 2AP.

In addition, the synthesis of GABA is regulated by $B A D H 2$. In aromatic rice varieties, since $B A D H 2$ is nonfunctional, low GABA synthesis takes place. However, the amount of GABA present in P. amaryllifolius was considerably higher. The concentrations of GABA in various plant parts commonly range from 0.03 to $5.5 \mu \mathrm{g} / \mathrm{g}$ fresh weight [22]. This study demonstrated higher levels of proline and methylglyoxal that might be responsible for the high 2AP expression in P. amaryllifolius. BADH2 enzyme activity leads to an increased level of its substrate, GAB-ald, the immediate precursor of 2AP [36]. Utilization of GAB-ald by converting it into GABA blocks $2 \mathrm{AP}$ synthesis, whereas the enhancement of GAB-ald results in increased 2AP synthesis.

\subsection{BADH2-Independent 2AP Synthesis in P. amaryllifolius?}

Considering the functionality of $\mathrm{PaBADH} 2$ in P. amaryllifolius, along with high 2AP synthesis, raises the question of how $2 \mathrm{AP}$ is synthesized in P. amaryllifolius. Interestingly, Huang et al. [34] reported that in aromatic rice, the upregulation of P5CS might be associated with the higher levels of delta-1-pyrroline-5-carboxylic acid, thus showing accumulation of a high amount of 2AP. The analysis of the expression level of $\Delta^{1}$-pyrroline5-carboxylic acid synthetase and the enhanced concentration of its product among fragrant and nonfragrant varieties exhibited that $2 \mathrm{AP}$ is synthesized by the direct reaction of methylglyoxalwithdelta-1-pyrroline-5-carboxylate independent of BADH2 [37]. In another study, Huang et al. [34] studied an in vitro model system and demonstrated that methylglyoxal was one of the main precursors for 2AP synthesis. Methylglyoxal might react directly with $\Delta^{1}$-pyrroline-5- carboxylic acid, derived from L-proline by purified recombinant $B$. subtilis ssp. natto PRODH, and lead to the formation of 2-acetyl-1-pyrroline. The overproduced $\Delta^{1}$-pyrroline-5-carboxylic acid may be detoxified by methylglyoxal and results in the biosynthesis of 2AP. In our analysis, we recorded comparatively higher levels of P5CS and methylglyoxal in P. amaryllifolius. Therefore, ultimately, this mechanism might be existing in P. amaryllifolius, which might be responsible for high 2AP synthesis independent of $\mathrm{PaBADH} 2$ (Figure 8).

Moreover, fragrance is a trait of high value in rice. The Discovery of the recessive fragrance gene in rice Bradbury et al. [10] has facilitated the breeding of fragrant rice. The same gene has been linked with fragrance in sorghum and other plant species. The loss of function of the $B A D H 2$ gene [10] that results in fragrance is associated with a loss of performance that may be due to stress susceptibility caused by the disruption of a pathway that is a key stress response mechanism in plants [12]. Pandanus leaves have the same fragrance but are much more resistant to stresses, such as salt [38], than fragrant rice varieties. Understanding the biochemical processes in Pandanus may support the breeding of higher-yielding stress-tolerant rice and other crops that are also fragrant. 


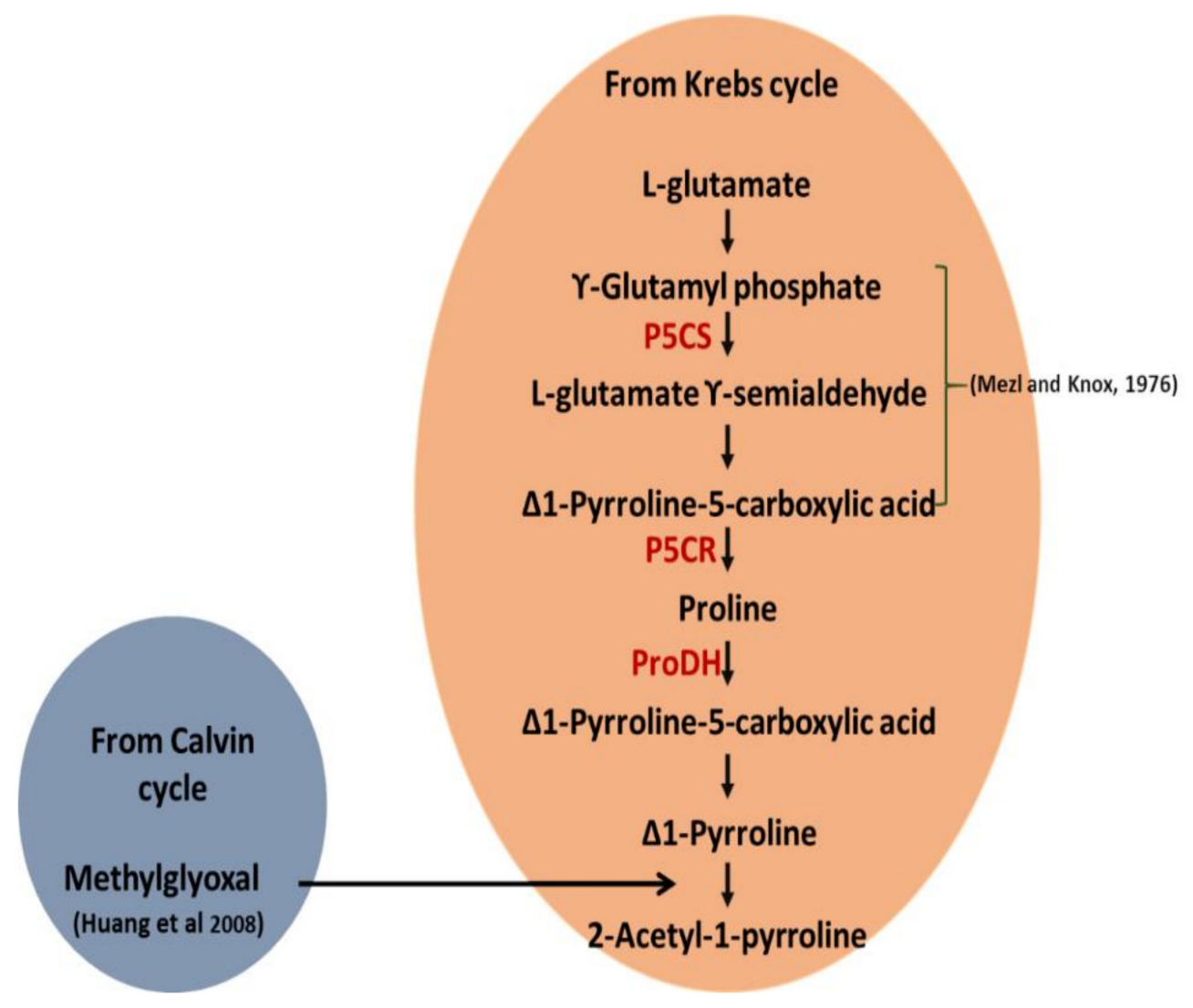

Figure 8. Proposed 2AP biosynthetic pathway in P. amaryllifolius, highlighting enzymes used in biosynthesis of 2AP in P. amaryllifolius.P5CS: 1 1-pyrroline-5-carboxylate synthetase; P5CR: $\Delta 1$ pyrroline-5-carboxylate reductase; ProDH: proline dehydrogenase.

\section{Material and Methods}

\subsection{Plant Material}

One-year-old seedlings of P. amaryllifolius, maintained at the Botanical garden of Department of Botany, Savitribai Phule Pune University, Pune, Maharashtra, were used for transcriptome analysis, estimation of metabolites, enzyme assay, and gene expression analysis. The seeds of fragrant (Basmati 370) and nonfragrant (IR64) rice cultivars were obtained from the Maval region, Maharashtra, and Indian agriculture research institute (IARI) New Delhi, India, respectively. For the estimation of metabolites, enzyme assay, and gene expression analysis, leaves of 45-day-old rice seedlings and one-year-old plantlets of P. amaryllifolius were used.

\subsection{Transcriptome Analysis}

For transcriptome analysis, total RNA was extracted from the leaf tissue of P. amaryllifolius using a Qiagen RNeasy Plant Mini Kit (Qiagen, Germany), following the manufacturer's protocol, and DNase I treatment at $37^{\circ} \mathrm{C}$ for $30 \mathrm{~min}$ was used to remove any potential genomic DNA contamination. The quality and quantity of isolated RNA were checked using a Nanodrop (ND-1000) spectrophotometer (Thermo Fisher Scientific, Waltham, MA, USA) and by analyzing the RNA samples on a $1 \%$ agarose gel. The quality of the RNA samples was further checked on a Bioanalyzer 2100 (Agilent technologies, Singapore). A sample with an RNA integrity number (RIN) of more than 7 was used for RNA sequencing analysis.

\subsection{RNA Sequencing, De Novo Assembly, and Functional Annotation of Unigenes}

Paired-end libraries of 150bp read length were sequenced using a HiSeq 2500 system (Illumina, San Diego, CA, USA) by SciGenom, Kochi, India. The raw sequence data 
generated were analyzed through the following steps. The raw data were filtered using an NGSQC Toolkit (v2.3.3 NIPGR, New Delhi, India) to remove adaptor sequences and reads with low quality (Phred) scores $(Q \geq 30)$. Only high-quality reads were further used for de novo transcriptome assembly using Trinity (v2.2) pipeline [39]. The resulting trinity assembly was made non-redundant using CD-HIT (v4.6.1). The assembled unigene sequences were annotated using BLASTx (E-value $\leq 1 \mathrm{E}^{-5}$ ) (http:/ / www.ncbi.nlm.nih.gov / BLAST/) (accessed on 18 February 2019) against the National Center for Biotechnology Information (NCBI) database of non redundant protein (Nr) (http:/ / www.ncbi.nlm.nih. gov) (accessed on 18 February 2019) [40].

\subsection{Isolation of PaBADH2 Gene Using Transcriptome Sequence}

A standalone blastable database of the assembled transcriptome was established using the ViroBLAST tool [41]. The nucleotide sequence of the $P a B A D H 2$ gene was retrieved from the transcriptome data by using TBlastNtool with the Rice BADH2 protein sequence.

\subsection{PaBADH2 Transcript Comparative Sequence Analysis}

In order to study the gene and protein sequences, the isolated nucleotide sequence of the $\mathrm{PaBADH} 2$ gene was compared with previously reported P. amaryllifolius BADH2 (PND BADH2, gene ID: KY765936.1) and a nonfragrant rice BADH2 (gene ID: 4345606)gene. $O s B A D H 2$ and $P N D B A D H 2$ sequences were retrieved from the NCBI database, along with their respective amino acid sequences. Using expasy translate tools (http:/ / www. expasy.org/) (accessed on 18 February 2019), the PaBADH2 nucleotide sequence was translated. The sequences were aligned together with the ClustalW 1.8 program (http: / /www.ebi.ac.uk/clustalw/) (accessed on 18 February 2019).

\subsection{Homology Modeling and Molecular Docking of BADH2}

The amino acid sequences of PaBADH2 and nonfragrant rice (gene ID 4345606) were further used for protein structure prediction through SWISS-MODEL (https://swissmodel. expasy.org/interactive) (accessed on 18 February 2019). The homology modeling was performed using Zea mays AMADH (aminoaldehyde dehydrogenase) as a template. To study the enzyme-substrate interaction, BAD was taken as a substrate. The structural details of both the substrates were collected from the PubChem database. The AutoDockVina (Vina) [42] docking tool was used for ligand flexible docking simulations. The structures of the templates and the refined model of PaBADH2 were set up as the receptors for the docking protocol. The structure data file (SDF) of the ligand molecule was downloaded from PubChem (http:/ / pubchem.ncbi.nlm.nih.gov) (accessed on 18 February 2019), and docking was performed at the acceptor and donor binding sites, as reported earlier [27]. The molecular docking was performed between OsBADH2 and PaBADH2 with BAD as a substrate.

\subsection{Estimation of BADH Enzyme Activity}

The BADH activity of $100 \mathrm{mg}$ protein isolated from P. amaryllifolius, Basmati 370 (scented rice), and IR 64 (nonscented rice) was measured with BAD and GAB-ald as substrates following the method of Weretilnyk et al. [43].

\subsection{Quantitative Real-Time Expression of BADH2 Gene}

Total RNA was isolated from leaf tissues of Basmati 370 (scented), IR-64 (nonscented) rice varieties, and P. amaryllifolius. $1 \mu \mathrm{g}$ of RNA of the selected plant species was used to carry out first-strand cDNA synthesis using RevertAidTM M-MuLV Kit (Fermentas, Waltham, Massachusetts, USA). For qPCR analysis, $\mathrm{PaBADH} 2$ and $\mathrm{OsBADH} 2$ gene-specific primers were designed through Primer 3.0 software (http://biotools.umassmed.edu/ bioapps / primer3_www.cgi) (accessed on 18 February 2019) (Table 1). The PCR conditions for the BADH2 were optimized using gradient PCR (Eppendorf, Hamburg, Germany) for real-time expression analysis. The BADH2 expression analysis was performed in the 
Mastercycler ep realplex system (Eppendorf, Hamburg, Germany) using iQ SYBR Green Supermix (Bio-Rad, Hercules, CA, USA). The real-time quantitative PCR was carried out in a total volume of $25 \mu \mathrm{L}$ containing $12.5 \mu \mathrm{lSYBR}$ Green, $1 \mu \mathrm{L}$ of each forward and reverse primer $(10 \mathrm{pmol} / \mu \mathrm{L}), 1 \mu \mathrm{L}$ of Cdna, and $9.5 \mu \mathrm{L}$ water. The PCR conditions were kept as follows: $95{ }^{\circ} \mathrm{C}$ for $10 \mathrm{~min}$ one cycle; $95{ }^{\circ} \mathrm{C}, 30 \mathrm{~s} ; 56{ }^{\circ} \mathrm{C}, 30 \mathrm{~s} ; 72{ }^{\circ} \mathrm{C}, 1 \mathrm{~min}$ for 40 cycles were performed in triplicates and repeated twice. The diluted cDNA (1:4) was amplified with the primers based on a gene of interest, and the $\mathrm{Ct}$ values generated were used to prepare the standard curve. Initial copy numbers of unknown samples were calculated by using Step One Real-Time software absolute quantification model. The elongation factor 1 (EF1) housekeeping gene was used as an internal control to normalize the expression of the target gene, and relative expressions of $B A D H 2$ were measured following the $2^{-\triangle \triangle C T}$ method [44]. The transcript abundance was calculated as fold change/10 ng of cDNA.

Table 1. Primers used for $P a B A D H 2$ real-time expression analysis.

\begin{tabular}{|c|c|}
\hline Name of Primer & Primer Sequences \\
\hline F Pan BADH2 (Pandanus) & 5'TGTTGTAAGTCAAGGACAGTATGC3' $^{\prime}$ \\
\hline $\mathrm{R}$ Pan BADH2 (Pandanus) & 5'CCGCССАССТССАAATAATATAG3' \\
\hline F Rice $B A D H 2$ (Rice) & 5' ATTTGTATCTACCGCCAAAAGC3' \\
\hline R Rice $B A D H 2$ (Rice) & 5'CGACATCAGTAATGATTGTGGGT3' \\
\hline F Pan P5CS (Pandanus) & 5'GAGGCAGCAACAAGCTTGT3' \\
\hline R Pan P5CS (Pandanus) & 5'GTGTACAAGAAGGGTTTCCAT3' \\
\hline F Rice P5CS (Rice) & 5'GAAGTGGTAATGGTCTTCTC $3^{\prime}$ \\
\hline R Rice P5CS (Rice) & 5'AGCAAATCTGCGATCTCATC3' \\
\hline
\end{tabular}

\subsection{Quantification of 2AP Using HS-SPME with GC-MS}

The quantification of 2AP in P. amaryllifolius and aromatic rice seeds was carried out using HS-SPME with GC-MS, as previously described by Wakte et al. [8] and Hinge et al. [45], respectively. Briefly, a $4 \mathrm{~mL}$ screw-top vial $(15 \times 45 \mathrm{~mm})$ with PTFE silicone septa (Chromatography Research Supplies, Louisville, KY, USA) was used to take $100 \mathrm{mg}$ leaf material (powdered) of $P$. amaryllifolius. The samples were incubated for $10 \mathrm{~min}$ at $80^{\circ} \mathrm{C}$ for equilibration. The $1 \mathrm{~cm}$-long SPME fiber coated with carboxen/divinyl-benzene/poly-dimethylsiloxane (CAR/DVB/PDMS) was used for adsorption of volatiles for $25 \mathrm{~min}$. the volatile compounds were recognized with respect to the presence of specific ions, their respective ratio, and comparing the MS spectra with the reference spectra from the National Institute of Standards and Technology (NIST, ver. 2.0f, 2008) mass spectral database. A series of $\mathrm{n}$-alkanes ( $\mathrm{C} 8$ to $\mathrm{C} 20$ ) was used for calculating retention indices [46]. The 2AP concentration was measured using an external standard method with 2,4,6-trimethylpyridine (TMP) as a reference standard [47].

\subsection{Quantification of Proline, Methylglyoxal, and GABA}

GABA and proline concentration in leaf samples of P. amaryllifolius, Basmati 370 (scented rice), and IR 64 (nonscented rice) were estimated using the standard method described by Gay et al. [48] and Bates et al. [49], respectively. For the estimation of methylglyoxal, initial isolation was carried out following the method of Yadav et al. [21], and quantification was performed according to Wild et al. [50].

P5CS enzyme activity was assayed following the method of García-Ríos et al. [51], with minor modifications. The P5CS gene expression analysis was carried out in a similar way, as described for the $B A D H 2$ gene using P5CS gene-specific primers. 


\section{Conclusions}

In the present study, we report a full-length functional sequence of the PaBADH2 gene from transcriptome data of $P$. amaryllifolius. Further qPCR and BADH2 enzyme activity confirmed the functionality of PaBADH2 protein. P. amaryllifolius is considered to accumulate 2AP to the highest levels. Similarly, the metabolites and enzymes related to 2AP biosynthesis were also in high concentration. Although there is the presence of functional BADH2 protein, 2AP synthesis is abundant, which suggests that a different molecular mechanism might be involved in 2AP biosynthesis in P. amaryllifolius, which still needs to be explored. This mechanism can further be employed in the breeding of rice to develop an aromatic rice variety that is resistant to yield loss under stress conditions. The high concentrations of proline may support the generation of high concentrations of GAB-ald in sufficient concentrations so that the presence of an active BADH2 converting the GAB-ald to GABA may not deplete the GAB-ald to levels that prevent reaction with the high concentrations of methylglyoxal to produce $2 \mathrm{AP}$.

Supplementary Materials: The following are available online at https:/ /www.mdpi.com/article/10 .3390/ijms22136968/s1, Table S1: Primary assembly statistics of the P. amaryllifolius transcriptome.

Author Contributions: Conceptualization A.N.; methodology, A.N.; software, V.T.B., V.B. and A.F.; validation, V.B.; formal analysis, V.B.; investigation, V.B.; resources, A.N.; data curation, V.B.; writingoriginal draft preparation, V.B.; writing-review and editing, A.N., A.F. and R.J.H.; visualization, A.N., R.J.H.; supervision, A.N., R.J.H., A.F. and V.T.B.; project administration, A.N. All authors have read and agreed to the published version of the manuscript.

Funding: No funding was received to assist with the preparation of this manuscript.

Institutional Review Board Statement: Not applicable.

Informed Consent Statement: Not applicable.

Data Availability Statement: The data presented in this study will be openly available after one year of publication. The SRA sequence have been deposited in NCBI with the project ID: PRJNA692823.

Conflicts of Interest: The authors declare no conflict of interest.

\section{References}

1. Buttery, R. Identification of rice aroma compound 2-acetyl-1-pyrroline in pandan leaves. Chem. Ind. 1983, $1983,478$.

2. Wongpornchai, S.; Sriseadka, T.; Choonvisase, S. Identification and quantitation of the rice aroma compound, 2-acetyl-1-pyrroline, in bread flowers (Vallaris glabra Ktze). J. Agric. Food Chem. 2003, 51, 457-462. [CrossRef] [PubMed]

3. Nadaf, A.; Krishnan, S.; Wakte, K. Histochemical and biochemical analysis of major aroma compound (2-acetyl-1-pyrroline) in basmati and other scented rice (Oryza sativa L.). Curr. Sci. 2006, 91, 1533-1536.

4. Bhattacharjee, P.; Kshirsagar, A.; Singhal, R.S. Supercritical carbon dioxide extraction of 2-acetyl-1-pyrroline from Pandanus amaryllifoliusRoxb. Food Chem. 2005, 91, 255-259. [CrossRef]

5. Vartak, V. Note on Ambemohor Pat (Pandanus amaryllifoliusRoxb.) from western India. J. Bombay Nat. Hist. Soc. 1981, 78, 196-198.

6. Wakte, K.V.; Nadaf, A.B.; Krishnan, S.; Thengane, R.J. Studies on lower epidermal papillae, the site of storage of basmati rice aroma compounds in Pandanus amaryllifoliusRoxb. Curr. Sci. 2007, 93, 238-242.

7. Wakte, K.V.; Kad, T.D.; Zanan, R.L.; Nadaf, A.B. Mechanism of 2-acetyl-1-pyrroline biosynthesis in BassialatifoliaRoxb. flowers. Physiol. Mol. Biol. Plants 2011, 17, 231-237. [CrossRef]

8. Wakte, K.V.; Thengane, R.J.; Jawali, N.; Nadaf, A.B. Optimization of HS-SPME conditions for quantification of 2-acetyl-1-pyrroline and study of other volatiles in Pandanus amaryllifoliusRoxb. Food Chem. 2010, 121, 595-600. [CrossRef]

9. Wakte, K.V.; Zanan, R.L.; Saini, A.; Jawali, N.; Thengane, R.J.; Nadaf, A.B. Genetic diversity assessment in Pandanus amaryllifoliusRoxb. populations of India. Genet. Res. Crop Evol. 2012, 59, 1583-1595. [CrossRef]

10. Bradbury, L.M.; Fitzgerald, T.L.; Henry, R.J.; Jin, Q.; Waters, D.L. The gene for fragrance in rice. Plant Biotechnol. J. 2005, 3, 363-370. [CrossRef]

11. Bradbury, L.M.; Gillies, S.A.; Brushett, D.J.; Waters, D.L.; Henry, R.J. Inactivation of an aminoaldehyde dehydrogenase is responsible for fragrance in rice. Plant Mol. Biol. 2008, 68, 439-449. [CrossRef]

12. Fitzgerald, T.L.; Waters, D.L.E.; Brooks, L.O.; Henry, R.J. Fragrance in rice (Oryza sativa) is associated with reduced yield under salt treatment. Environ. Exp. Bot. 2010, 69, 223. [CrossRef]

13. Farres, J.; Wang, T.T.; Cunningham, S.J.; Weiner, H. Investigation of the active site cysteine residue of rat liver mitochondrial aldehyde dehydrogenase by site-directed mutagenesis. Biochemistry 1995, 34, 2592-2598. [CrossRef] 
14. Perez-Miller, S.J.; Hurley, T.D. Coenzyme isomerization is integral to catalysis in aldehyde dehydrogenase. Biochemistry 2003, 42, 7100-7109. [CrossRef]

15. Wang, X.; Weiner, H. Involvement of glutamate 268 in the active site of human liver mitochondrial (class 2) aldehyde dehydrogenase as probed by site-directed mutagenesis. Biochemistry 1995, 34, 237-243. [CrossRef]

16. Cheetangdee, V.; Chaiseri, S. Free amino acid and reducing sugar composition of pandan (Pandanus amaryllifolius) leaves. Agric. Nat. Res. 2006, 40, 67-74.

17. Thimmaraju, R.; Bhagyalakshmi, N.; Narayan, M.; Venkatachalam, L.; Ravishankar, G. In vitro culture of Pandanus amaryllifolius and enhancement of 2-acetyl-1-pyrroline, the major flavouring compound of aromatic rice, by precursor feeding of L-proline. J. Sci. Food Agric. 2005, 85, 2527-2534. [CrossRef]

18. Suprasanna, P.; Ganapathi, T.; Ramaswamy, N.; Surendranathan, K.; Rao, P. Aroma synthesis in cell and callus cultures of rice. Rice Genet News 1998, 15, 123-125.

19. Yoshihashi, T.; Nguyen, T.T.H.; Kabaki, N. Area dependency of 2-acetyl-1-pyrroline content in an aromatic rice variety, Khao Dawk Mali 105. Jpn. Agric. Res. Q. 2004, 38, 105-109. [CrossRef]

20. Arora, V.; Sultana, M.; Kumar, V.; Gangopadhyay, G. Isolation and characterization of BADH2 gene from in vitro propagated Pandanus amaryllifoliusRoxb. Plant. Cell Tissue Organ Cult. 2017, 130, 131-140. [CrossRef]

21. Yadav, S.K.; Singla-Pareek, S.L.; Ray, M.; Reddy, M.; Sopory, S. Methylglyoxal levels in plants under salinity stress are dependent on glyoxalase I and glutathione. Biochem. Biophys. Res. Commun. 2005, 337, 61-67. [CrossRef] [PubMed]

22. Shelp, B.J.; Mullen, R.T.; Waller, J.C. Compartmentation of GABA metabolism raises intriguing questions. Trends Plant Sci. 2012, 17, 57-59. [CrossRef] [PubMed]

23. Rashmi, D.; Nadaf, A. Understanding the Mechanism of Salt Tolerance in Pandanus odorifer L. Proc. Natl. Acad. Sci. India Sect. B Biol. Sci. 2018, 88, 1557-1563. [CrossRef]

24. Kaikavoosi, K.; Kad, T.D.; Zanan, R.L.; Nadaf, A.B. 2-Acetyl-1-pyrroline augmentation in scented indica rice (Oryza sativa L.) varieties through $\triangle 1$-pyrroline-5-carboxylate synthetase (P5CS) gene transformation. Appl. Biochem. Biotechnol. 2015, 177, 1466-1479. [CrossRef] [PubMed]

25. Rashmi, D.; Barvkar, V.T.; Nadaf, A.; Mundhe, S.; Kadoo, N.Y. Integrative omics analysis in Pandanus odorifer (Forssk.) Kuntze reveals the role of Asparagine synthetase in salinity tolerance. Sci. Rep. 2019, 9, 932. [CrossRef] [PubMed]

26. Tylichová, M.; Kopečný, D.; Moréra, S.; Briozzo, P.; Lenobel, R.; Snégaroff, J.; Šebela, M. Structural and functional characterization of plant aminoaldehyde dehydrogenase from Pisum sativum with a broad specificity for natural and synthetic aminoaldehydes. J. Mol. Biol. 2010, 396, 870-882. [CrossRef] [PubMed]

27. Baicharoen, A.; Vijayan, R.; Pongprayoon, P. Structural insights into betaine aldehyde dehydrogenase (BADH2) from Oryza sativa explored by modeling and simulations. Sci. Rep. 2018, 8, 12892. [CrossRef]

28. Kopečný, D.; Tylichová, M.; Snegaroff, J.; Popelková, H.; Šebela, M. Carboxylate and aromatic active-site residues are determinants of high-affinity binding of $\omega$-aminoaldehydes to plant aminoaldehyde dehydrogenases. FEBS J. 2011, 278, 3130-3139. [CrossRef]

29. Mann, C.J.; Weiner, H. Differences in the roles of conserved glutamic acid residues in the active site of human class 3 and class 2 aldehyde dehydrogenases. Protein Sci. 1999, 8, 1922-1929. [CrossRef]

30. Kamaraj, B.; Purohit, R. In-silico analysis of Betaine Aldehyde Dehydrogenase2 of Oryza sativa and significant mutations responsible for fragrance. J. Plant Interact. 2013, 8, 321-333. [CrossRef]

31. Srivong, P.; Wangsomnuk, P.; Pongdontri, P. Characterization of a fragrant gene and enzymatic activity of betaine aldehyde dehydrogenase in aromatic and nonaromatic thai rice cultivars. KKU Sci. J. 2008, 36, 290-301.

32. Arakawa, K.; Katayama, M.; Takabe, T. Levels of betaine and betaine aldehyde dehydrogenase activity in the green leaves, and etiolated leaves and roots of barley. Plant Cell Physiol. 1990, 31, 797-803.

33. Hien, N.L.; Yoshihashi, T.; Sarhadi, W.A.; Hirata, Y. Sensory test for aroma and quantitative analysis of 2-acetyl-1-pyrroline in Asian aromatic rice varieties. Plant Product. Sci. 2006, 9, 294-297. [CrossRef]

34. Huang, T.-C.; Teng, C.-S.; Chang, J.-L.; Chuang, H.-S.; Ho, C.-T.; Wu, M.-L. Biosynthetic mechanism of 2-acetyl-1-pyrroline and its relationship with $\Delta 1$-pyrroline-5-carboxylic acid and methylglyoxal in aromatic rice (Oryza sativa L.) callus. J. Agric. Food Chem. 2008, 56, 7399-7404. [CrossRef]

35. Wu, M.L.; Chou, K.L.; Wu, C.R.; Chen, J.K.; Huang, T.C. Characterization and the possible formation mechanism of 2-acetyl-1pyrroline in aromatic vegetable soybean (Glycine max L.). J. Food Sci. 2009, 74, S192-S197. [CrossRef]

36. Chen, S.; Yang, Y.; Shi, W.; Ji, Q.; He, F.; Zhang, Z.; Cheng, Z.; Liu, X.; Xu, M. Badh2, encoding betaine aldehyde dehydrogenase, inhibits the biosynthesis of 2-acetyl-1-pyrroline, a major component in rice fragrance. Plant Cell 2008, 20, 1850-1861. [CrossRef]

37. Sakthivel, K.; Sundaram, R.; Rani, N.S.; Balachandran, S.; Neeraja, C. Genetic and molecular basis of fragrance in rice. Biotechnol. Adv. 2009, 27, 468-473. [CrossRef]

38. Fitzgerald, T.L.; Waters, D.L.E.; Henry, R.J. The effect of salt on betaine aldehyde dehydrogenase transcript levels and 2-acetyl-1pyrroline concentration in fragrant and non-fragrant rice (Oryza sativa). Plant Sci. 2008, 175, 539-546. [CrossRef]

39. Haas, B.J.; Papanicolaou, A.; Yassour, M.; Grabherr, M.; Blood, P.D.; Bowden, J.; Couger, M.B.; Eccles, D.; Li, B.; Lieber, M. De novo transcript sequence reconstruction from RNA-seq using the Trinity platform for reference generation and analysis. Nat. Protoc. 2013, 8, 1494-1512. [CrossRef]

40. Altschul, S.F.; Gish, W.; Miller, W.; Myers, E.W.; Lipman, D.J. Basic local alignment search tool. J. Mol. Biol. 1990, 215 , 403-410. [CrossRef] 
41. Deng, W.; Nickle, D.C.; Learn, G.H.; Maust, B.; Mullins, J.I. ViroBLAST: A stand-alone BLAST web server for flexible queries of multiple databases and user's datasets. Bioinformatics 2007, 23, 2334-2336. [CrossRef]

42. Trott, O.; Olson, A.J. AutoDock Vina: Improving the speed and accuracy of docking with a new scoring function, efficient optimization, and multithreading. J. Comput. Chem. 2010, 31, 455-461. [CrossRef]

43. Weretilnyk, E.A.; Hanson, A.D. Betaine aldehyde dehydrogenase from spinach leaves: Purification, in vitro translation of the mRNA, and regulation by salinity. Arch. Biochem. Biophys. 1989, 271, 56-63. [CrossRef]

44. Livak, K.J.; Schmittgen, T.D. Analysis of relative gene expression data using real-time quantitative PCR and the $2-\Delta \Delta C T$ method. Methods 2001, 25, 402-408. [CrossRef]

45. Hinge, V.R.; Patil, H.B.; Nadaf, A.B. Aroma volatile analyses and 2AP characterization at various developmental stages in Basmati and Non-Basmati scented rice (Oryza sativa L.) cultivars. Rice 2016, 9, 38. [CrossRef]

46. Van Den Dool, H.; Kratz, P.D. A generalization of the retention index system including linear temperature programmed gas-liquid partition chromatography. J. Chromatogr. A 1963, 11, 463-471. [CrossRef]

47. Grimm, C.C.; Champagne, E.T.; Lloyd, S.W.; Easson, M.; Condon, B.; McClung, A. Analysis of 2-acetyl-1-pyrroline in rice by HSSE/GC/MS. Cereal Chem. 2011, 88, 271-277. [CrossRef]

48. Gay, F.; Maraval, I.; Roques, S.; Gunata, Z.; Boulanger, R.; Audebert, A.; Mestres, C. Effect of salinity on yield and 2-acetyl-1pyrroline content in the grains of three fragrant rice cultivars (Oryza sativa L.) in Camargue (France). Field Crops Res. 2010, 117, 154-160. [CrossRef]

49. Bates, L.S.; Waldren, R.P.; Teare, I. Rapid determination of free proline for water-stress studies. Plant Soil 1973, 39, $205-207$. [CrossRef]

50. Wild, R.; Ooi, L.; Srikanth, V.; Münch, G. A quick, convenient and economical method for the reliable determination of methylglyoxal in millimolar concentrations: The N-acetyl-L-cysteine assay. Anal. Bioanal. Chem. 2012, 403, 2577-2581. [CrossRef] [PubMed]

51. García-Ríos, M.; Fujita, T.; LaRosa, P.C.; Locy, R.D.; Clithero, J.M.; Bressan, R.A.; Csonka, L.N. Cloning of a polycistronic cDNA from tomato encoding $\gamma$-glutamyl kinase and $\gamma$-glutamyl phosphate reductase. Proc. Natl. Acad. Sci. USA 1997, 94, 8249-8254. [CrossRef] 